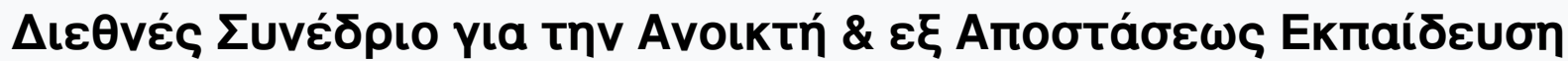

Tón. 5, Ap. 1A (2009)

Open and Distance Education for Global Collaboration \& Educational Development

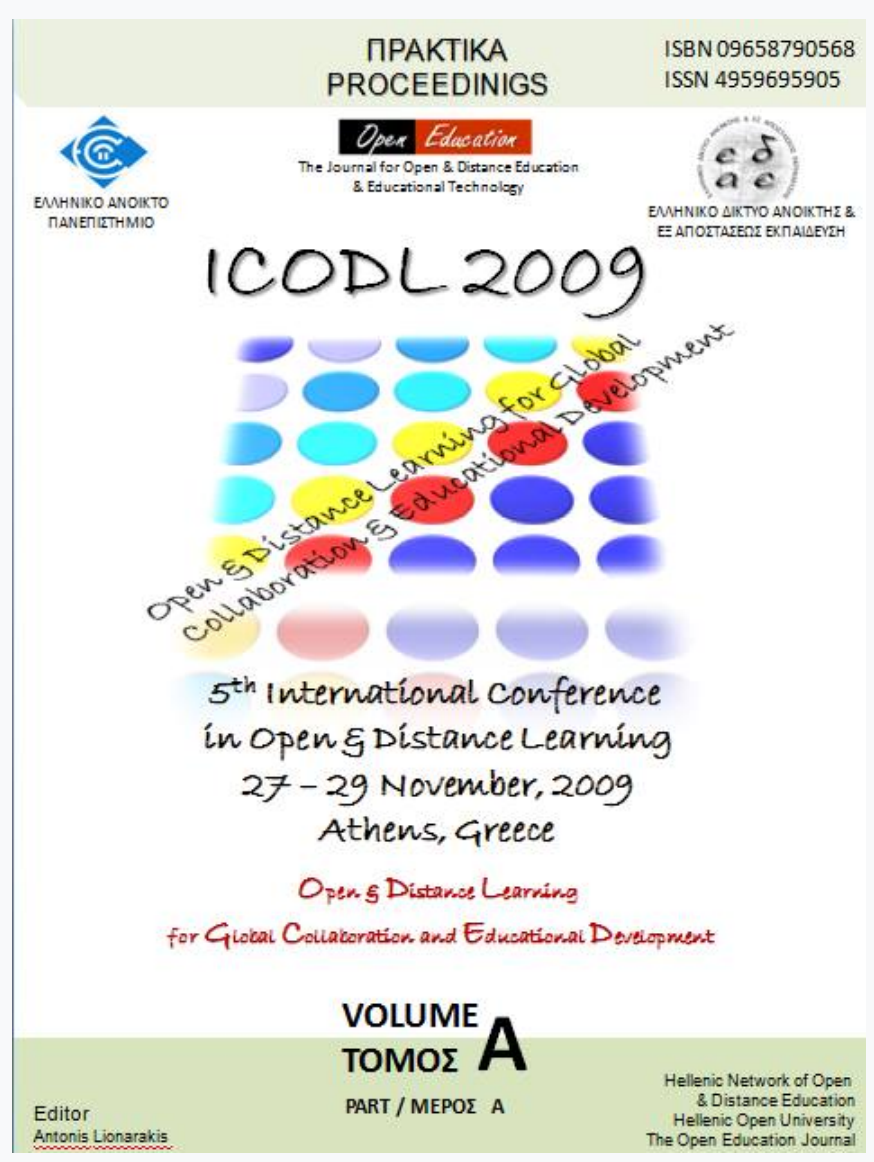

\begin{abstract}
A Discussion of the Similarities and Differences in the Contexts and Practices of Open and Distance Education in Developed and Developing Countries Dimitris ZONDIROS
\end{abstract}

doi: $10.12681 /$ icodl.429 
$5^{\text {th }}$ International Conference in Open \& Distance Learning - November 2009, Athens, Greece - PROCEEDINGS

\title{
A Discussion of the Similarities and Differences in the Contexts and Practices of Open and Distance Education in Developed and Developing Countries
}

\author{
Dimitris ZONDIROS \\ Lecturer, Technological Education Institution (T.E.I.) of Athens, \\ zondiros@otenet.gr
}

\begin{abstract}
Open and Distance Education enjoys the acceptance and support from governments in most countries of the world. However, their motives (e.g. why do they support Open and Distance Education provision) and contexts as well as the subsequent practices are quite different as they correspond to their priorities. But there are some (less) similarities also. These differences and similarities were examined and ascribed to the social / cultural, economic, political / ideological and technological factors that compose the backbone of each developed and developing country. The nature and importance of the differences suggest that there no "turn-key" solutions regarding Open and Distance Education. The challenge is to find the successful match between priorities and solutions.
\end{abstract}

\section{Key words}

Open and Distance Education, developed / developing countries, similarities, differences, contexts, practices.

\section{Introduction}

The purpose of this paper is to discuss the similarities and differences in the contexts and practices of Open and Distance Education in developed and developing countries. To do so, it starts with the definitions of the terms to be used and continues with locating and commenting on these similarities and differences. It attempts to achieve this by drawing on the literature on the subject and to demonstrate the resulting contrasting interpretations of Open and Distance Education.

\section{Defining terms and concepts}

Many things have been written about the terms "distance learning" and "distance education". The same does not apply to the term "distance teaching". However, all definitions (Peters, 1973, Moore, 1973, Holmberg, 1977 and 1994, Delling, 1987, Tight, 1988, Moore and Kearsley 1996) have some elements in common:

- A physical separation (in terms of time and/or space) of the teacher and the student.

- Instructional design that separates teaching from learning 
- Some kind of exchange / interaction (in terms of questions, answers, advice, guidance, support etc.) between teacher and learner.

- Use of technology to mediate teaching and learning (Lea and Blake, 2004).

- Increased flexibility for the student (e.g. time and pace of study).

Therefore, we can infer that both "distance teaching" and "distance learning" are the main elements of a two-way process and communication (through technology) between students and tutors resulting in feedback (from tutors) on students' effort to gain the knowledge, skills and attitudes required. But this is exactly what we call "education". Thus, we can adopt and use Keegan's equation (1997): "distance teaching + distance learning = distance education". The term "distance education" is more comprehensive and precise (UNESCO, 2002) despite the every-day usage of the term "distance learning". Juler (1990: 24) puts it in the right context: 'Distance education means creating educational communities which teachers, students and others are linked in discourse wherever they may be through networks appropriate to their circumstances'.

Things are quite different when referring to "open learning". The term "open education" is rarely used and the term "open teaching" not at all. This is normal as the learner is at (or becomes) the epicentre of the educational process (at least, in the mission statements of ODE institutions). Again, definitions (Coffey, 1997, Lewis and MacDonald, 1988, Johnson, 1992) have in common the fact that "open learning" "... involves helping learners take responsibility for aspects such as what they learn, how they learn, where they learn, how quickly they learn who to turn for help and whether, when and where to have their learning assessed" (UNESCO, 2002). On the other hand, Hawkridge (1997) explains the imposed limitations to all these and $\mathrm{Hu}$ sets the requirements of successful open learning:

- The more learners may choose in learning process, the more 'open' learning process will be

- The more accesses, the more opportunities

- The more flexible, the more open and

- The more fair, the more success (Hu, 1995: 329).

Therefore, Open Learning and Distance Education may be combined. The open learning concept is greater, more difficult to define and can include and use distance education. So, for the purposes of this paper, the term Open and Distance Education (hereinafter ODE) will be used.

\section{Assumptions for the discussion}

Before discussing the similarities and differences in the contexts and practices of developing and developed regions, the following assumptions have to be made:

1) the use of some broad categories / factors as starting points for the discussion must be viewed as a matter of convenience only and

2) none of these factors can stand alone - each one has interconnections and is interwoven with the others in ways that cannot always be found and clarified (see below).

\section{Similarities and differences in the contexts and practices of developing and developed regions of the world}


The following tables will enable us to see the similarities and differences in the contexts and practices of developing and developed regions and the resulting contrasting interpretations of ODE. Some factors will be used to facilitate this task. These are the social and cultural, economic, political and ideological and technological factors. Table 1 shows the similarities and Table 2 the differences in the contexts and practices of developing and developed regions. This analysis draws heavily on Perraton's (2000) work on the subject.

\section{Table 1}

Similarities in the contexts and practices of developing and developed regions

\begin{tabular}{|l|l|}
\hline \multicolumn{1}{|c|}{ Developing and developed regions } \\
\hline CULTURAL & \multicolumn{1}{|c|}{} \\
\hline & $\begin{array}{l}\text { Both saw ODE as means for widening access to education for major } \\
\text { parts of the population (UNESCO, 2002, Taylor et al, date not } \\
\text { available). }\end{array}$ \\
\hline $\begin{array}{l}\text { Both considered ODE as a means for meeting the growing demand for } \\
\text { education and training (Manjulika and Venugopal, 2002, Gaba and } \\
\text { Panda, 2005). }\end{array}$ \\
\hline $\begin{array}{l}\text { Both established Open Universities capable of accepting large } \\
\text { numbers of students - the bigger of them 'with over 100.000 active } \\
\text { students in degree-level courses' are called 'Mega Universities' } \\
\text { (Daniel, 1996: 29). }\end{array}$ \\
\hline $\begin{array}{l}\text { ODE was seen as an educational method that allows people to work } \\
\text { and study at the same time. }\end{array}$ \\
\hline $\begin{array}{l}\text { Acceptance of ODE as a concept and method of education grew } \\
\text { enormously (UNESCO, 2002). }\end{array}$ \\
\hline $\begin{array}{l}\text { Both were partially successful in reaching disadvantaged people - this } \\
\text { must be viewed in conjunction with other factors in each society (e.g. } \\
\text { poverty that generates poverty due to lack of education, social } \\
\text { discrimination, minorities' standing, etc.) (Khan, 2005). }\end{array}$ \\
\hline $\begin{array}{l}\text { ODE was seen as means for using existing resources to serve more } \\
\text { people, thus being more efficient (UNESCO, 2002). }\end{array}$ \\
\hline $\begin{array}{l}\text { ODE was seen as a tool for cost effectiveness because large and costly } \\
\text { infrastructures (campuses etc.) can be avoided. }\end{array}$ \\
\hline $\begin{array}{l}\text { The above two were considered to be the answer to the problem of } \\
\text { financial constraints and difficulties. }\end{array}$ \\
\hline $\begin{array}{l}\text { Both sought to combine the (perceived) cost effectiveness and } \\
\text { efficiency with quality and standards maintenance. }\end{array}$ \\
\hline $\begin{array}{l}\text { They both understood that efficiency threatens flexibility and vice } \\
\text { versa because flexibility requires diversification of, say, the media } \\
\text { used and, hence, is adding to cost. }\end{array}$ \\
\hline $\begin{array}{l}\text { They both were forced to accept that what is needed in any case and in } \\
\text { any ODE system is the good teaching material - lack of it erodes all } \\
\text { other advantages because it results in high drop-out rates, waste of } \\
\text { resources and poor learning experiences for the learners (mainly the }\end{array}$ \\
\hline
\end{tabular}




\begin{tabular}{|l|l|}
\hline & $\begin{array}{l}\text { amount of student interaction). ODE does not ask for buildings etc. } \\
\text { but asks for investment in intellectual capital through staff } \\
\text { development, help to teachers to undertake new roles and cover the } \\
\text { cost of material production and distribution (Lewis, 1998, Mandell } \\
\text { and Herman, 1996). }\end{array}$ \\
\hline POLITICAL - & $\begin{array}{l}\text { Governments expressed their commitment in establishing and } \\
\text { supporting ODE but they were not aware of the whole picture. Many } \\
\text { countries do not wish to use programmes originating elsewhere but } \\
\text { lack the expertise in developing high-quality materials and support } \\
\text { structures, fail to choose the appropriate current and future } \\
\text { technologies or ignore the fact that sound financial planning and } \\
\text { management are needed to ensure sustainability (Potashnik and } \\
\text { Capper, 1998). }\end{array}$ \\
\hline $\begin{array}{l}\text { Governments tried to response to the demands posed by economic } \\
\text { development, the public demand and the need for widening access. }\end{array}$ \\
\hline $\begin{array}{l}\text { There is evidence that ODE has failed to meet the expectations held } \\
\text { upon it about educational expansion and access - the causes of this } \\
\text { can be attributed to other factors also, e.g. social, economic and } \\
\text { technological (Zondiros, 2008). }\end{array}$ \\
\hline TECHNOLOGICAL \\
$\begin{array}{l}\text { Print is the media mostly used in both regions - this is normal due to } \\
\text { its advantages. But there are exceptions: for example, China used a } \\
\text { different technology in the form of TV broadcasts to reach their } \\
\text { student population. }\end{array}$ \\
$\begin{array}{l}\text { Both seem to accept Daniel's (1996: 56) notion: Technologies that } \\
\text { are popular with students, academics and administrators are likely to } \\
\text { be successful'. }\end{array}$ \\
$\begin{array}{l}\text { The adoption of new technologies is not driven by their } \\
\text { appropriateness in achieving particular teaching and learning } \\
\text { outcomes (Lea and Blake, 2004). The degree of experimentation with } \\
\text { new technologies is high but it is unsure if the technological tools fit } \\
\text { the appropriate pedagogical models (Chee, 2002, Maor, 2004). }\end{array}$ \\
\hline
\end{tabular}

Table 2

Differences in the contexts and practices of developing and developed regions

\begin{tabular}{|l|l|l|}
\hline \multicolumn{1}{|c|}{ Developing regions } & \multicolumn{1}{c|}{ Developed regions } \\
\hline $\mathbf{S}$ & ODE has a short history of about 50-60 & ODE has a long history of about 100-150 \\
$\mathbf{O}$ & years. & $\begin{array}{l}\text { years and, therefore, there is more } \\
\text { experience gained. }\end{array}$ \\
$\mathbf{C}$ & \multicolumn{1}{|c|}{ Is } \\
$\mathbf{I}$ & ODE serves younger students than in & ODE mainly serves 35-40 year old adults. \\
$\mathbf{A}$ & developed regions (Kawachi, 2007). & \\
\hline
\end{tabular}




\begin{tabular}{|c|c|c|}
\hline $\begin{array}{l}\mathbf{L} \\
- \\
\mathbf{C} \\
\mathbf{U} \\
\mathbf{L} \\
\mathbf{T} \\
\mathbf{U} \\
\mathbf{R} \\
\mathbf{A} \\
\mathbf{L}\end{array}$ & $\begin{array}{l}\text { Demand for higher education differs among } \\
\text { regions but is generally higher than previous } \\
\text { years (Bekhradnia and Bailey, 2008, Howell } \\
\text { et al, 2003). }\end{array}$ & $\begin{array}{l}\text { Demand for higher education remains } \\
\text { relatively stable - more emphasis is given to } \\
\text { continuing and lifelong education and ODE } \\
\text { is considered as a valued alternative to } \\
\text { achieve this aim (Bates, 1995). }\end{array}$ \\
\hline \multirow{5}{*}{$\begin{array}{l}\mathbf{E} \\
\mathbf{C} \\
\mathbf{O} \\
\mathbf{N} \\
\mathbf{O} \\
\mathbf{M} \\
\mathbf{I} \\
\mathbf{C}\end{array}$} & $\begin{array}{l}\text { ODE is expected to meet the needs of an } \\
\text { economy based in manufacturing due to } \\
\text { lower labour cost - this a result and a cause } \\
\text { (at the same time) of a 'knowledge divide' } \\
\text { (Manjulika and Venugopal, 2002). }\end{array}$ & $\begin{array}{l}\text { ODE is expected to meet the needs of a } \\
\text { knowledge-based economy (Bates, 1995, } \\
\text { Howell et al, 2003, O' Lawrence, 2007). }\end{array}$ \\
\hline & ODE cost is covered mostly by public funds. & $\begin{array}{l}\text { ODE institutions have begun to expect } \\
\text { students to pay their own fees for the } \\
\text { increased flexibility the offer. }\end{array}$ \\
\hline & $\begin{array}{l}\text { Lack of resources is always a constraint for } \\
\text { ODE in these countries. }\end{array}$ & $\begin{array}{l}\text { There are resources but many "players" fight } \\
\text { for them (conventional institutions, etc.). }\end{array}$ \\
\hline & $\begin{array}{l}\text { Any economic upheaval has negative impact } \\
\text { on the money spent on ODE (Baldacci et al, } \\
\text { 2002). }\end{array}$ & $\begin{array}{l}\text { Any economic upheaval has a much less } \\
\text { negative impact on the money spent on } \\
\text { ODE. }\end{array}$ \\
\hline & $\begin{array}{l}\text { High dropout rates erode ODE's } \\
\text { comparative advantage over conventional } \\
\text { education - lack of adequate support and } \\
\text { guidance may explain this (Bartels and } \\
\text { Willen, 1985, Shin and Kim, 1999, } \\
\text { UNESCO, 2002). }\end{array}$ & $\begin{array}{l}\text { Dropout rates are usually lower, mainly } \\
\text { because learners are managed in a different } \\
\text { way (guidance and support provision) } \\
\text { (Rumble, 1992, Kiser, 1999, Wang et al, } \\
\text { 2004). }\end{array}$ \\
\hline $\begin{array}{l}\text { P } \\
\text { O } \\
\text { L } \\
\text { I } \\
\text { T }\end{array}$ & $\begin{array}{l}\text { The need for expansion and access is mainly } \\
\text { a result of the fact that these regions are } \\
\text { developing and require more well-educated } \\
\text { workforce. }\end{array}$ & $\begin{array}{l}\text { The need for expansion is mainly a result of } \\
\text { the fact that these regions are already } \\
\text { developed and want to extend learning } \\
\text { opportunities over the whole life span } \\
\text { (UNESCO, 2002). }\end{array}$ \\
\hline $\begin{array}{l}\text { I } \\
\text { C } \\
\text { A } \\
\text { L }\end{array}$ & $\begin{array}{l}\text { Expansion through ODE is seen as an } \\
\text { answer to geographical constraints in vast } \\
\text { countries with millions of people (potential } \\
\text { students) (Visser, 1994). }\end{array}$ & $\begin{array}{l}\text { Expansion through ODE is not so much seen } \\
\text { as a response to geographical constraints. }\end{array}$ \\
\hline$\overline{\mathbf{I}}$ & $\begin{array}{l}\text { Access in higher education does not focus } \\
\text { on certain disadvantaged groups. }\end{array}$ & $\begin{array}{l}\text { Access in higher education focuses (more or } \\
\text { less) on certain disadvantaged groups. }\end{array}$ \\
\hline
\end{tabular}




\begin{tabular}{|c|c|c|}
\hline $\begin{array}{l}\mathbf{D} \\
\mathbf{E} \\
\mathbf{O} \\
\mathbf{L} \\
\mathbf{O} \\
\mathbf{G} \\
\mathbf{I} \\
\mathbf{C} \\
\mathbf{A} \\
\mathbf{L}\end{array}$ & $\begin{array}{l}\text { Developing countries try to "borrow" } \\
\text { lessons learned from the developed ones on } \\
\text { their ODE effort (Harry and Perraton, 1999). } \\
\text { There is evidence they also try to learn from } \\
\text { the developed countries' mistakes } \\
\text { (Ramanujam, 1997, Butcher, 2000, Khan et } \\
\text { al, 2001). }\end{array}$ & $\begin{array}{l}\text { Developed countries deal more with the } \\
\text { ways ODE systems are structured aiming at } \\
\text { effectiveness and efficiency (Baumeister, } \\
\text { 1995, Shale, 1995, King, 1995). }\end{array}$ \\
\hline $\begin{array}{l}\mathbf{T} \\
\mathbf{E} \\
\mathbf{C} \\
\mathbf{H} \\
\mathbf{N}\end{array}$ & $\begin{array}{l}\text { Choices of technology for ODE were made } \\
\text { in terms of reaching people who could not } \\
\text { be expected to have campus-based education } \\
\text { (Lea and Blake, 2004, Khan, 2005). }\end{array}$ & $\begin{array}{l}\text { Choices of technology for ODE were made } \\
\text { in terms of reaching people who did not } \\
\text { have the opportunity to be educated and } \\
\text { addressing the needs of working people who } \\
\text { could not leave their jobs. }\end{array}$ \\
\hline $\begin{array}{l}\text { O } \\
\mathbf{L} \\
\mathbf{O} \\
\mathbf{G}\end{array}$ & $\begin{array}{l}\text { Choices of technology were made in terms } \\
\text { of reaching people inside each country. }\end{array}$ & $\begin{array}{l}\text { Choices of technology were made in terms } \\
\text { of reaching people who were resident out of } \\
\text { the country - to widen the catchment areas } \\
\text { (Blight, Davies and Olsen, 1999). }\end{array}$ \\
\hline $\begin{array}{l}\text { I } \\
\text { C } \\
\text { A } \\
\text { L }\end{array}$ & $\begin{array}{l}\text { Lack of basic infrastructures led to the } \\
\text { extensive use of print in ODE - for other } \\
\text { infrastructures to be established, political } \\
\text { support were needed, e.g. China (UNESCO, } \\
\text { 2002). }\end{array}$ & $\begin{array}{l}\text { The existence of appropriate infrastructures } \\
\text { did not answer the problem of learners' } \\
\text { access to the necessary equipment - new } \\
\text { technologies may narrow access if they } \\
\text { become a barrier to learning (Zondiros, } \\
\text { 2008). New technologies' adoption requires } \\
\text { a lot of time. }\end{array}$ \\
\hline & $\begin{array}{l}\text { Recent technological developments augment } \\
\text { the 'digital divide' - this must be taken } \\
\text { account along with the 'knowledge divide' } \\
\text { (Manjulika and Venugopal, 2002). }\end{array}$ & $\begin{array}{l}\text { Developed countries have the knowledge to } \\
\text { produce and support digital technology but } \\
\text { face problems of a different nature (e.g. } \\
\text { access, cost, faculty / staff development, } \\
\text { etc.) (Haughey and Anderson, 1998, Lewis, } \\
\text { 1998, Mason, 1994). }\end{array}$ \\
\hline & $\begin{array}{l}\text { Delivery of ODE from person-based to } \\
\text { print-based. }\end{array}$ & $\begin{array}{l}\text { Delivery of ODE from print-based to new } \\
\text { media. }\end{array}$ \\
\hline
\end{tabular}

\section{Conclusion}

Variable circumstances and different priorities drive developed and developing countries in choosing different issues to address and different strategies to implement regarding ODE. But both are subject to the same condition as it is expressed by Daniel (1999: 298) as a plea: 'I conclude with the plea that we discipline ourselves to specify more clearly the particular dimensions of openness we seek to develop through open learning and the educational objectives that we wish to achieve by distance education. There are many challenges facing education and training that open learning and distance education can help us to meet. However, there are no 
panaceas and we should make clear in each case how we are trying to match solutions and problems'.

\section{References}

Baldacci, Em., de Mello, L. and Inchauste, G. (2002). 'Financial Crises, Poverty and Income Distribution', Finance and Development, 39 (2), Retrieved on 9 May, 2009 from http://www.imf.org/external/pubs/ft /fandd/2002/06/baldacci.htm.

Bartels, J. and Willen, Br. (1985). 'Drop-Out: Problems of Comparing Drop-Out in Different Distance Education Systems'. Paper presented at the 13th World Conference of the International Council of Distance Education (ICDE), Melbourne, Australia, August 13-20.

Bates, A. W. (1995). 'Creating the Future: Developing Vision in Open and Distance Learning' in Lockwood, F., ed., Open and Distance Learning Today. London, Routledge.

Baumeister, H-P. (1995). 'Western Europe' in Lockwood, F., ed., Open and Distance Learning Today. London, Routledge.

Bekhradnia, B. and Bailey, N. (2008). 'Demand for Higher Education to 2029', Higher Education Policy Institute (HEPI) Report, Retrieved on 12 May, 2009 from www.hepi.ac.uk/downloads/39DemandforHEto2029 summary.doc.

Blight, D., Davies, D. and Olsen, A. (1999). 'The Internationalisation of Higher Education', in Harry, K., ed., Higher Education through Open and Distance Learning, London, Routledge.

Butcher, N. (2000), Distance Education in Developing Countries - Imfundo KnowledgeBank paper 3, Retrieved on 10 May, 2009 from http://imfundo.digitalbrain.com/imfundo/web/teach/documents/kb3/kb3.pdf.

Chee, Y. S. (2002). 'Refocusing Learning on Pedagogy in a Connected World', On the Horizon, 10 (4), pp. 7-13.

Daniel, J. (1996). Mega Universities and Knowledge Media - Technology Strategies for Higher Education, London, Kogan Page.

Daniel, J. (1996). 'Open Learning and / or Distance Education: Which one for What Purpose?' in Harry, K., ed., Higher Education through Open and Distance Learning, London, Routledge.

Gaba, Ash. and Panda, S. (2005). 'Open and Distance Education in Global Environment: Some Economic Issues Developing Countries'. Paper presented at the International Conference of the International Council for Open and Distance Education (ICDE), November 19-23, New Delhi, India, Retrieved on 26 May, 2009 from www.ignou.ac.in/ICDE2005/PDFs/theme1pdf/theme1_10.pdf.

Harry, K. and Perraton, H. (1999). 'Open and Distance Learning for the New Society', Harry, K., ed., Higher Education through Open and Distance Learning, London, Routledge.

Haughey, M. and Anderson, T. (1998). Networked Learning: the Pedagogy of the Internet, Montrèal, Toronto, Chenelière / McGraw - Hill.

Hawkridge, D. (1997). H801 Foundations of Open and Distance Education, Block 1, Theory and Practice in Open and Distance Education, Milton Keynes, The Open University / Deakin University, University of South Australia.

Holmberg, B. (1977). Distance Education: A Survey and Bibliography, London, Kogan Page.

Holmberg, B. (1994). Foundations of Distance Education, Unit 1, revised edition translated into Hellenic (Greek) for TRIA Project, Zentrales Institut für FernstudienForschung (ZIFF) - FernUniversität - Gesampthochschule - in Hagen.

Howell, S. L., Williams, P. B. and Lindsay, N. K. (2003). 'Thirty-two Trends Affecting Distance Education: An Informed Foundation for Strategic Planning', Online Journal of Distance Learning Administration, 6 (3), pp. 1-18, Retrieved on 10 May, 2009 from http://www.westga.edu/ distance/ojdla/fall63/howell63.html.

Hu, M-C. (1995). 'Beyond Distance Teaching Towards Open Learning: A Conceptual Analysis of Transformation, Characteristics and Approaches', Journal of National Chung Cheng University, Sec. I: Humanities [on-line], 6 (1), pp. 325-344, Retrieved on 26 May, 2009 from http://www.kuleuven.ac.be/iccp/ 2001/iccp2/pdf/mengchinghu.pdf .

Johnson, R. (1992). 'Open Learning: Unseen Issues', in Goldman, S., ed., Good Practice for Flexible Delivery, Adelaide, TAFE National Staff Development Committee.

Juler, P. (1990). 'Promoting Interaction; Maintaining Independence: Swallowing the Mixture', Open Learning, 5 (2), pp. 24-33. 
Kawachi, P. (2007). 'New Opportunities for Universities throughout Asia - the International Professors Project', The Asian Journal of Distance Education, 5 (1), pp. 65-68, Retrieved on 10 May, 2009 from http:// www.asianjde.org/2007v5.1.Kawachi.pdf.

Keegan, D. (1996). Foundations of Distance Education, London, Routledge.

Khan, A. W. (2005). 'Distance Education for Development'. Keynote address to the International Conference on Open Learning and Distance Education of the International Council for Open and Distance Education (ICDE), November 19-23, New Delhi, India.

Khan, J. A., Khan, S. A. and Al-Abaji, R. H. (2001). 'Prospects of Distance Education in Developing Countries'. Paper presented at the International Conference on Millennium Dawn in Training and Continuing Education, April 24-26, University of Bahrain, Bahrain, Retrieved on 26 May, 2009 from http://www.ece.ubc.ca/ junaidk/ papers/pap7.pdf.

King, B. (1995). 'Distance Education in Australia', in Lockwood, F., ed., Open and Distance Learning Today, London, Routledge.

Kiser, K. (1999). 'Ten Things we Know so far about Online Learning', Training, November, 36 (11), pp. 66-74.

Lea, M. and Blake, N. (2004). H805 Understanding Distributed and Flexible Learning, Block 1, From 'Distance' and 'Open' to 'Flexible' Learning, Milton Keynes, The Open University.

Lewis, R. (1998). 'Staff Development in Conventional Institutions Moving towards Open Learning' in Latchem, C. and Lockwood, F., eds, Staff Development in Open and Flexible Learning, London, Routledge.

Mandell, A. and Herman, L. (1996). 'From Teachers to Mentors: Acknowledging Openings in the Faculty Role' in Mills, R. and Tait, A., eds, Supporting the Learner in Open and Distance Learning, London, Pitman.

Manjulika. S. and Venugopal R. V. (2002). Towards Virtualization: Open and Distance Learning, New Delhi, Kogan Page.

Maor, D. (2004). 'Pushing Beyond the Comfort Zone: Bridging the Gap between Technology and Pedagogy', in Atkinson, R., McBeath, C., Jonas-Dwyer, D. and Phillips, R. (eds). Beyond the Comfort Zone. Proceedings of the 21st ASCILITE Conference, December 5-8, Perth, pp. 572-576, Retrieved on 26 May, 2009 from http:// www.ascilite.org.au/conferences/perth04/procs/maor.html.

Mason, R. (1994). 'Implications for Students, Teachers and Organisations', ch. 3 in Communications Media in Open and Flexible Learning, London, Kogan Page.

Moore, M. G. and Kearsley, G. (1996). Distance Education: A Systems View, Belmont, California, Wadsworth.

Moore, M. G. (1973). 'Towards a Theory of Independent Learning and Teaching', Journal of Higher Education, 44, pp. 661-697.

O' Lawrence, H. (2007). 'An Overview of the Influences of Distance Learning on Adult Learners', Journal of Education and Human Development, 1 (1), Retrieved on 22 May, 2009 from http://www.scientificjournals.org/ journals2007/articles/1041.htm.

Perraton, H. (2000). Open and Distance learning in the Developing World, London, Routledge.

Peters, O. (1973). Die Didaktische Struktur des Fernunterrrichts, Weinheim, Beltz,

Potashnik, M. and Capper, J. (1998). 'Distance Education: Growth and Diversity', Finance and Development, March, 35 (1), pp. 42-45, Retrieved on 10 May, 2009 from http://www.worldbank.org/fandd/english/pdfs/0398/ 0110398.pdf.

Ramanujam, P. R. (1997). 'Distance Education in Developing Countries: Prospects and Challenges'. Paper presented at the International Conference of the International Council for Open and Distance Education (ICDE), June, Pennsylvania, USA, Retrieved on 10 May, 2009 from www.egyankosh.ac.in/bitstream/ 123456789/25052/1/Unit-9.pdf.

Rumble, G. (1992). The Management of Distance Learning Systems. Paris, UNESCO / International Institute for Educational Planning (IIEP).

Shale, D. (1995). 'University Distance Education in Canada', in Lockwood, F., ed., Open and Distance Learning Today, London, Routledge.

Shin, N. and Kim, J. (1999). 'An Exploration of Learner Progress and Drop-Out in Korea National Open University', Distance Education, 20 (1), pp. 81-95.

Taylor, G., Mellor, L. and Walton, L. (date not available). 'The Politics of Widening Participation: A Review of the Literature', Retrieved on 10 May, 2009 from http:/extra.shu.ac.uk/alac/CommunityInvolvement/ wideningparticipation.html.

United Nations Educational Scientific and Cultural Organisation (UNESCO) (2002). Open and Distance Learning: Trends, Policy and Strategy Considerations, Paris. 
Visser, J. (1994). 'Distance Education for the Nine High Population Countries: A Concept Paper', Paris, UNESCO, Basic Education Division, Retrieved on 10 May, 2009 from http://www.unesco.org/education/ educprog/lwf/doc/de9.html.

Wang, J., Wu, E. and Wong, P. (2004). 'Strategies for Reducing Dropout from Distance Education Courses', in G. Richards (ed). Proceedings of World Conference on E-Learning in Corporate, Government, Healthcare and Higher Education, pp. 1705-1710, Chesapeake, VA, Association for the Advancement of Computing in Education (AACE).

Zondiros, D. (2008). 'Online, Distance Education and Globalisation: Its Impact on Educational Access, Inequality and Exclusion', European Journal of Open, Distance and E-Learning (EURODL), Access to Education special issue, Retrieved on 16 May, 2009 from http://www.distanceandaccesstoeducation.org/ or www.eurodl.org/materials/special/2008/Dimitris_Zondiros_GBA.htm. 